\title{
Obituary
}

Prof. Fran Jesenko

$\mathrm{Y}$ UGOSLAV science, and the University of Ljubljana in particular, has suffered an irreparable loss by the untimely death, on July 16, of Prof. Fran Jesenko, professor of botany at the University of Ljubljana, in consequence of an accident in the Julian Alps.

Jesenko was born near Ljubljana in 1875 . He was educated there and in Vienna, where he graduated in 1902 . In 1901 he was appointed tutor to two Oriental princes at the Teresianum, the wellknown college for boys in Vienna. A similar appointment in the family of Count A. Merveldt, with whom he travelled to Egypt, gave him a good opportunity to study the desert flora. He was afterwards commissioned by the Vienna Botanical Institute to study the flora of Petræa, and at that time he also visited Persia, whilst he was the first Slovene to travel through the Sahara. Upon his return from his travels he studied in Uppsala and Paris. It was during his stay in Sweden that he became an expert in ski-running, and throughout his life he always found time to cultivate that sport.

On his return to Vienna, Jesenko was appointed assistant to Prof. Czermak at the Vienna School of Agriculture, and in 1913 lecturer at the Vienna Botanical Institute. It was during this period that he began to devote himself to what may be described as his life work, namely, the evolving of a fertile cross between wheat and rye. At the fourth International Conference on Genetics, held in Paris in 1911, he was able to report the progress of his experiments in a paper, "Sur un hybride fertile entre Triticum stativum et Seccale cereale", whilst at the time of his death his research had advanced so far that the next step would have been the cultivation of the new cereal on a fairly large scale at an experimental farm.

Jesenko was corresponding member of scientific societies in Great Britain, America, Tokyo, Leningrad, Uppsala, and Paris. We may quote a few of his early works as follows: "Beziehungen zwischen der Lichtintensität und dem anatomischen Bau der assimilierenden Organe von Wüstenpflanzen " (1907) ; " Einige neue Verfahren die Ruheperiode der Holzgewächse abzukürzen " (1911-12); " Über das Austreiben im Sommer entblatterten Baume und Straucher" (1912); "Versuche über die Turgenszensdauer abgeschittener Pflanzensprosse" (1910); and "Utber Getreide-spezies-Bastarde (Weizen-Roggen)" (1913).

In 1914 he was called up for active service, and during the War suffered seven months' internmentin Bohemia, because of his sympathies with the Slav cause and the Allies. After the War, his opportunity came with the constitution of the new Yugoslav State. In 1919, Jesenko was first appointed lecturer, and then professor of botany at the University of Zagreb, and in the following year was transferred to the newly founded University at Ljubljana. Here he had all the hard work, but also the satisfaction, which attends pioneer work. He soon conceived the plan of marking off part of the famous Triglav Lakes Valley as a national park, a plan which, in spite of great difficulties, he succeeded in realising.

On July 12, Jesenko set off to join his students at their headquarters in the Triglav Lakes Valley. It is assumed that whilst stepping aside from the steep path up the Komarcha Crag to look at some plant, his heavy pack caused him to overbalance on the precipitous and treacherous slope. He was found by some tourists a little later, his spine broken. He was removed to Ljubljana Hospital, where he died on July 16.

Jesenko was an able linguist and spoke fifteen languages. He possessed a beautiful singing voice; at one time indeed it seemed doubtful whether he might not choose the career of a public singer. His death will be widely deplored, but most of all by his students, whom he imbued with his own enthusiasm and devotion to his work, whilst all who had experience of his kindness and generosity will regret the premature death of the man no less than that of the naturalist.

\section{Mr. Herbert Knapman}

IN Herbert Knapman, registrar of the University of Reading, who died on Aug. 14 at the age of fifty-two years, the lover of music and philosophy and the tireless organiser had long survived the brilliant mathematician who went to Cambridge from Rugby in 1898, was second wrangler in 1901 , Smith's prizeman in 1903, and a fellow of Emmanuel College from 1903 until 1909. He joined the staff of University College, Reading, in 1903 as a lecturer in mathematics. If as a teacher he inspired awe of himself rather than love of his subject, the intense thoroughness which was his second nature brought a measure of success, and for a time he was even interested in the technique of imparting knowledge. Nevertheless, the steady transfer of his energies to the field of administration was a congenial development, and although the co-ordination of innumerable details seemed to his colleagues sometimes to be a waste of his intellect, there is no reason for supposing that the services which he performed, especially just after the War and at the time of the foundation of the University, so much better than a man less able could have hoped to do, withheld him from any more valuable work that he might have accomplished. The only work which he did as a mathematician was on the Subject Index of Pure Mathematics for the Royal Society Catalogue of Scientific Papers.

Knapman's lifelong passion was for music, of which he had a wide and expert knowledge. His one published paper described some experiments in which he observed a series of harmonic undertones excited by a tuning-fork; the observations were forgotten until the effect was rediscovered twenty years later, and it is evidence of the extraordinary delicacy of Knapman's ear that while he recorded

$$
\text { No 281, VoL. 130] }
$$

